\title{
YUS 1 IISIA

\section{Geothermal Exploitation in a World Heritage Site: a Case Study of Gunung Leuser National Park}

\author{
Marsudi Triatmodjo; ; Agustina Merdekawati²; Sandy Nurvianto ${ }^{3}$; \\ Irkham Afnan Trisandi Hasibuan; ; I Gusti Putu Agung ${ }^{5}$ \\ 1,2,4,5 Faculty of Law, Universitas Gadjah Mada \\ ${ }^{3}$ Faculty of Forestry, Universitas Gadjah Mada \\ Corresponding author's email: agustina_merdekawati@ugm.ac.id
}

\begin{tabular}{|c|c|}
\hline Article Information & Abstract \\
\hline $\begin{array}{l}\text { Submitted : } 18 \text { January } 2021 \\
\text { Reviewed : } 30 \text { March } 2021 \\
\text { Accepted : } 06 \text { April } 2021\end{array}$ & $\begin{array}{l}\text { Act No. 21/2014 on Geothermal Energy is considered a solution to } \\
\text { the slow development of geothermal energy utilization for power } \\
\text { plants by opening the way for exploitation in conservation forest } \\
\text { areas. However, in practice such exploitation is still constrained }\end{array}$ \\
\hline $\begin{array}{l}\text { Keywords: } \\
\text { geothermal power plant; } \\
\text { Gunung Leuser National Park; } \\
\text { tropical rainforest } \\
\text { heritage of Sumatra }\end{array}$ & $\begin{array}{l}\text { because it often clashes with the conservation interest. This study } \\
\text { aims to review: (1) the role of Act No. 21/2014 as a legal justification } \\
\text { to conduct geothermal exploitation in Gunung Kembar and } \\
\text { Gunung Waihlup within the core zone of Gunung Leuser National } \\
\text { Park (GLNP), and (2) the potential impact of such exploitation on } \\
\text { the international recognition of Tropical Rainforest Heritage of }\end{array}$ \\
\hline $\begin{array}{l}\text { DoI: } 10.20961 / \text { yustisia. } \\
\text { v10i1.47797 }\end{array}$ & $\begin{array}{l}\text { Sumatra (TRHS) as a world heritage. This research is normative, } \\
\text { utilizing secondary data comprising of primary and secondary legal } \\
\text { materials. This research employs a qualitative method to analyze } \\
\text { the data. The results showed that Act No. } 21 / 2014 \text { cannot justify } \\
\text { geothermal exploitation activity within the core zone of GLNP. The } \\
\text { study also concluded that the geothermal power plant activity is } \\
\text { projected to have the potential to compromise TRHS recognition as } \\
\text { a world heritage site. }\end{array}$ \\
\hline
\end{tabular}

\section{Introduction}

Geothermal energy is one of Indonesia's energy sources in abundance, due to its geographical location. Data from the MEMR shows that Indonesia's geothermal potential reaches 29.543 MWe (MEMR, 2016, p. 3). However, this great potential is not comparable to the realization of its current utilization. Based on data, the utilization of geothermal energy by the year 2019 was only around 7.2\% (2130.7 MWe) (MEMR, 2019a), and its role in electricity generation contributes around $5 \%$ of the total national electricity generation in 2018 (MEMR, 2019b, p. 9).

\section{$94 \quad$ Yustisia Volume 10 Number 1 (Jan-Apr 2021) Geothermal Exploitation in a World Heritage Site...}


Geothermal is an environmentally friendly energy resource. Due to its huge potential, geothermal is hailed as one of the prominent types of new and renewable energy (hereinafter NRE), which its development is being promoted both in Government Regulation Number 79/2014 on National Energy Policy (hereinafter NEP) (National Energy Policy, 2014) and in Presidential Regulation Number 22/2017 on the General Plan for National Energy. Geothermal energy is aimed to be a significant contributor to the NRE sector to achieve the national energy mix target of $23 \%$ by 2025 and $31 \%$ by 2050. Given that geothermal energy has a prominent role in achieving the NRE mix, the utilization of geothermal energy found in GLNP would substantially impact achieving such targets.

The result of the Preliminary Geothermal Survey in 2015 until 2016 in Gunung Kembar, Gayo Lues Regency, Aceh Province shows that there is a geothermal reserve of 107 MWe located in the Gunung Kembar and Gunung Waihlup region within Gunung Leuser National Park (hereinafter GLNP) (MEMR, 2017, pp. 35-41). Such geothermal energy potential is enormous enough for a large-scale, sustainable, and environmentally friendly geothermal power plant (MEMR, 2019a, pp. 100-101).

If we were to build a geothermal power plant in GLNP (assuming that the installed geothermal power plant's capacity would be the same as the geothermal source's potential capacity of $107 \mathrm{MWe}$ ), the power plant would be ranked eighth with the largest capacity installed in Indonesia. That finding is based on the data of geothermal power plant capacity in Indonesia provided by the Ministry of Energy and Mineral Resources (hereinafter MEMR)(MEMR, 2019a).

GLNP is a conservation forest, as national parks are part of the nature conservation area. Referring to the Act No. 27/2003 on Geothermal Energy (which now has been repealed), it defines exploitation of geothermal energy as a mining process, which means such activity cannot be carried out in conservation forest areas. That was the case according to the provisions in Act No. 5/1990 on Conservation of Living Natural Resources and Their Ecosystems (hereinafter Biodiversity Conservation Act) and Act No. 41/1999 on Forestry (hereinafter Forestry Act), which prohibit mining activities from being carried out in conservation forests. Such provision was among the hurdle in exploiting geothermal energy in Indonesia, which is often located in conservation forest areas (Mary et al., 2017, pp. 217-237).

In 2014, the government enacted Act No. 21/2014 on Geothermal Energy, which repealed Act No. 27/2003. The enactment of Act No. 21/2014 is considered a solution to the stagnant development and utilization of geothermal energy in Indonesia, especially for geothermal sources located within conservation forest areas, as it paves the way for geothermal exploitation in conservation areas. The General Explanation of Geothermal Act 2014 par. 6 explains that the raison d'etre of the Act was to respond to the failure of Act $27 / 2003$ to create an optimum geothermal utilization because many of the geothermal sources are located in remote areas or within a conservation area. The geothermal sources found within a conservation area were yet to be utilized at all, and therefore there was a need to improve the exploitation activities in a planned and integrated manner to decrease fossil fuel dependency. 
However, there remains a question on whether exploitation for geothermal power plants (which is classified as an indirect utilization) may be undertaken in any areas of conservation forests or only in some specific areas. Such a question became an issue of discussion following the enactment of Act No. 21/2014. Generally, there are two categories of geothermal exploitation, namely: direct utilization and indirect utilization. Indirect utilization is an exploitation activity that involves transforming heat energy and/or fluid to electricity, which is the case for a geothermal power plant.

One of the discussions that spark a lot of support and disagreement is whether geothermal power plants may be built within GLNP (Gres, 2016; Merdeka, 2017). On the one hand, the Preliminary Geothermal Survey showed that the geological aspects of GLNP indicate a considerable Gunung of geothermal energy. On the other hand, according to the zoning map issued by the Directorate General of Forest Protection and Nature Conservation No. 27/2014, the exploration area in Gunung Kembar and Gunung Waihlup is located within the core zone. Such a zone is vital for the habitat and the protection of four key species: orangutan, Sumatran rhino, Sumatran tiger, and Sumatran elephant.

In addition, GLNP is also part of the Tropical Rainforest Heritage of Sumatra (hereinafter TRHS), which UNESCO has recognized as a world natural heritage site in 2004. Such fact needs to be considered if the geothermal power plant projects in GLNP were to proceed. The consequence of such recognition is the limitation of exploitation activities that can be carried out in the region, and extra-careful considerations need to be taken to prevent and mitigate harms inflicted on the living environment. Since 2011, TRHS has been added to the List of World Heritage in Danger, which means there have been activities that compromise its sustainability (WHCom, 2011). Therefore, it becomes essential to consider whether geothermal exploitation is feasible to be conducted in GLNP as a world heritage site.

Based on the issues presented above, this research attempts to answer the following questions:

1. whether geothermal exploitation activity is feasible to be conducted in Gunung Kembar and Gunung Waihlup within GLNP according to the laws and regulations; and

2. whether geothermal exploitation activity in Gunung Leuser National Park has the potential to affect the status of TRHS as a world natural heritage site according to the provisions in the World Heritage Convention and its operational guidelines.

The answers to the research questions above will give insights on the feasibility to conduct geothermal exploitation within conservation areas, in particular, within a world heritage site. The result of this study is expected to provide inputs to the policy makers in making a decision on the matter.

\section{Research Methods}

This research is normative, utilizing secondary data comprising of primary, and secondary legal materials collected through literature study. The research employs a qualitative method to analyze the data. The research was carried out in two stages: (1) studies related to the provisions governing geothermal exploitation for geothermal

$96 \quad$ Yustisia Volume 10 Number 1 (Jan-Apr 2021) Geothermal Exploitation in a World Heritage Site... 
power plants according to the relevant statutory regulations, and (2) studies related to the management and utilization of sites recognized as world heritage.

\section{Research Result and Discussion}

\section{A. The Legal Feasibility for Geothermal Exploitation in Gunung Kembar and Gunung Waihlup Within Gunung Leuser National Park}

Although Act No. 21/2014 has paved the way for geothermal power plant exploitation in conservation forest areas, it still leaves an issue of whether such activity can be conducted in all parts of conservation forest areas or only in some specific areas. Such issue exists because the provision of Article 5 only stipulates that the definition of "conservation forest area" is Nature Conservation Area (Kawasan Pelestarian Alam) and Nature Reserve Area (Kawasan Suaka Alam) both onshore and offshore. No provision stipulates if there is a limitation to the conservation forest area it is referring to. Therefore, the limitation of nature conservation areas and nature reservation areas that allow geothermal exploitation for power plants must refer to the provisions of the Biodiversity Conservation Act. Based on the provisions stipulated there, it is found that each of the two areas is comprised of several sectors that have different conditions as to what activities are allowed to be conducted in each sector, including but not limited to exploitation for geothermal power plants.

Article 14 of the Biodiversity Conservation Act stipulates that Nature Reserve Area comprises of nature sanctuary (cagar alam) and wildlife reserve areas (suaka margasatwa). Meanwhile, Article 29 stipulates that Nature Conservation Area comprises of national park, forest park, and nature park. Table 1 illustrates the scope of conservation forest areas according to the Biodiversity Conservation Act provisions.

Table 1. The scope of conservation forest

\begin{tabular}{|c|c|c|}
\hline \multirow[t]{2}{*}{ Conservation forest area } & $\begin{array}{l}\text { Nature Conservation } \\
\text { Area }\end{array}$ & $\begin{array}{l}\text { (1) National Park } \\
\text { (2) Forest Park } \\
\text { (3) Nature Tourism Park }\end{array}$ \\
\hline & Nature Reserve Area & $\begin{array}{l}\text { (1) Nature Reserve } \\
\text { (2) Wildlife Reserve }\end{array}$ \\
\hline \multicolumn{3}{|c|}{$\begin{array}{l}\text { Notes: } \\
\text { - Nature Conservation Area is "a region with specific characteristics, either on land or in } \\
\text { water, which has the function for the protection of life support systems, the preservation } \\
\text { of species diversity of plants and animals, as well as sustainable utilization of living } \\
\text { natural resources and its ecosystems." } \\
\text { - National Park is "a nature conservation area with an original ecosystem, managed } \\
\text { with a zoning system utilized for research, science, education, farming, tourism, and } \\
\text { recreation purposes." }\end{array}$} \\
\hline
\end{tabular}

Source: Compiled by the authors based on the Biodiversity Conservation Act, 1990

According to such findings, one may ask whether we can conclude that geothermal exploitation in GLNP is legally justified according to the provisions 
in Act No 21/2014. In answering this question, we must take into account that the Biodiversity Conservation Act divides conservation forests into five sectors (as illustrated in Table 1) and governs the activities conducted in each of the sectors. In general, the activities allowed to be conducted in the Nature Conservation Area are for education, science, research, supporting cultivation, tourism, and recreation purpses without reducing each area's main functions (Biodiversity Conservation Act, 1990). In particular, National Park will be managed by a zoning system that comprises of four zones, namely: core zone, jungle zone, utilization zone, and other zones as necessary (as illustrated in Table 2). In the utilization of a national park, any activity contrary to each zone's functions is prohibited. Specifically for utilization within core zone, it is stipulated a ban of any activity that would result in a change to the integrity of the core zone, which includes reducing, eliminating the functions and the width of the zone, as well as adding non-native species of plants and animals to the zone.

Table 2. The zoning system of a national park

\begin{tabular}{lll}
\hline & (1) Core Zone & \\
& (2) Jungle Zone & \\
(3) Utilization Zone & \\
National park & & (1) Maritime Protection Zone \\
& (2) Traditional Zone \\
necessary & (3) Rehabilitation Zone \\
& (4) Religious, Cultural, and \\
& (5) Special Zone
\end{tabular}

Source: Compiled by the authors from the Biodiversity Conservation Act and Living Environment and Forestry Ministerial Regulation No. P.76/Menlhk-Setjen/2015.

The Biodiversity Conservation Act provisions relating to the zoning system are regulated further by Environment and Forestry Ministerial Regulation No. P.76/Menlhk-Setjen/2015 on the Criteria for National Park Management Zones and Management Blocks for Nature Reserves, Wildlife Reserves, Forest Parks, and Nature Tourism Park (hereinafter Ministerial Regulation No. P.76/2015). Ministerial Regulation No. P.76/2015 is the operating regulation of Article 16 of Government Regulation No. 28/2011 in conjunction with Government Regulation No. 108 on The Management of Nature Reserve Areas and Nature Conservation Areas repealed the Forestry Ministerial Regulation No. P.56/ Menhut-III/ 2006 on The Guidelines for National Park Zoning System.

According to the provisions stipulated in Ministerial Regulation No. P.76/2015, it is found that geothermal exploitation for power plants cannot be conducted in all zones within a national park, rather only permissible in the utilization zone. Meanwhile, in the other three zones, namely the core zone, jungle zone, and other zones as necessary, geothermal utilization for power plants is prohibited. The core zone is defined as a national park area that is protected, to which no changes are allowed, which would reduce, eliminate the 
functions, and increase other non-native plant and animal species. Thus, Act No. 21/2014 does not justify geothermal energy exploitation in all parts of a national park. The provisions governing the activities in both the core zone and utilization zone are presented in Table 3.

Table 3. Provisions governing the use of core zone and utilization zone in the national park

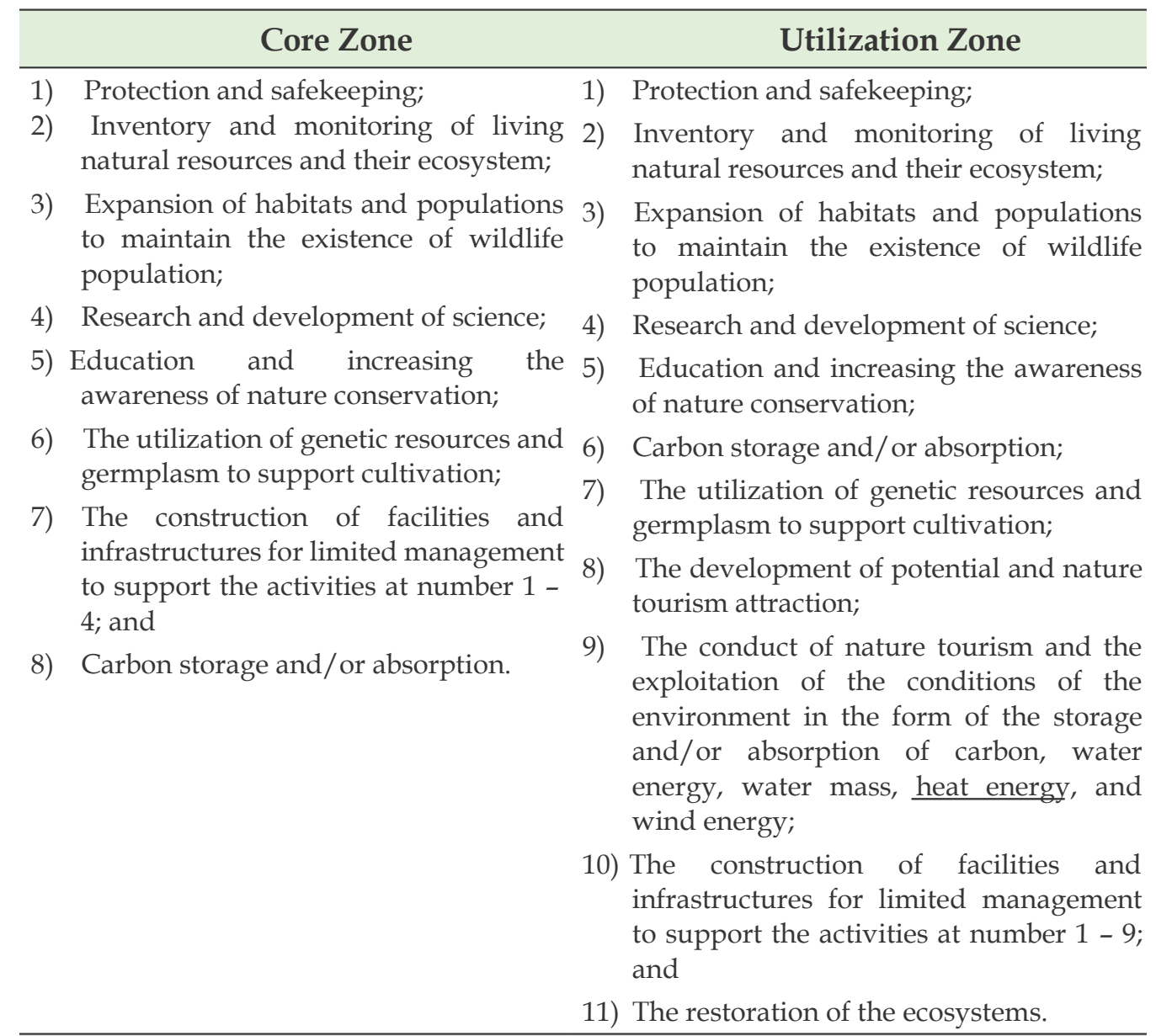

Note:

The complete matrix of the permissible activities in all four management zones and/ or blocks of the conservation forest can be accessed at the following link: http://bit.ly/ merdekawati2020_glnp.

Source: Compiled by the authors from Ministerial Regulation No. P.76/MenlhkSetjen/2015.

The Preliminary Geothermal Survey results indicated that geothermal potential is located in the vicinity of Gunung Kembar and Gunung Waihlup, located within the core zone of GLNP. Thus, according to Ministerial Regulation No P.76/2015, geothermal exploitation for power plant purposes cannot be conducted in the area. In connection with these facts, it can be concluded that the enactment of Act 21/2014 does not solve the issue of geothermal exploitation in GLNP, specifically in this case, the geothermal exploitation within its core zone. 
With the facts above, one may ask whether it is then impossible to utilize the geothermal power found in GLNP. According to the existing regulations, the government can still make efforts to conduct geothermal exploitation in GLNP. One of the options that can be taken by the government is to amend the provisions of the Biodiversity Conservation Act to accommodate geothermal exploitation better. Particularly for geothermal power plant purposes in the previously prohibited areas (including, but not limited to, such exploitation in the core zone). This strategy is one of the options offered in a paper by Sahide et al., which is to revise the Biodiversity Conservation Act by implementing the so-called 'liberal zoning' provision to open up access for geothermal projects in certain conservation forest areas (Sahide et al., 2018). However, this option has the risk of triggering a domino effect. Other interest groups would most likely also demand the same treatment in other utilization sectors, which would further compromise the conservation efforts.

Furthermore, it needs to be noted that at the moment, the push to revise the Biodiversity Conservation Act is based upon the spirit to improve the conservation efforts, which currently is deemed to be inadequate to safeguard the conservation areas, and the need to improve the law enforcement provisions. Therefore, the option to push for the amendment of the Biodiversity Conservation Act to better accommodate geothermal power plant exploitation will not be an easy task as it conflicts with society's demand.

Apart from the risk of triggering a domino effect that would compromise the conservation efforts, the efforts to amend the Biodiversity Conservation Act are expected to take a long time. There is no certainty as to when the completion would be. The plan to amend the Biodiversity Conservation Act had been added as a priority program in the National Legislation Program of 2015 - 2019, but it was left undiscussed (Prolegnas 2015-2019, 2015). The plan to revise the Biodiversity Conservation Act has also been added as one of the programs in the National Legislation Program of 2020 - 2024 (Prolegnas 2020$2024,2019)$ and recently was added to the list of prioritized National Legislation Program of 2021 (DPR decision on prioritized National Legislation Program of 2021). The attempt to revise the Act is not an easy task, not to mention that the foundation behind the effort to amend the Act is in the spirit of empowering the conservation efforts. This fact contradicts the option to revise the Act to accommodate better geothermal exploitation, which is considered an attempt to 'weaken' conservation efforts. Thus, the prospect of justifying geothermal exploitation activities in GLNP by revising the Biodiversity Conservation Act is an option that is not feasible shortly, at least according to the current trend.

Another option that the government can take to exploit the geothermal potential in GLNP is by attempting to change the management zone (i.e., redraw the zones or rezoning) through the procedures stipulated in Article 28 paragraph (1) of Ministerial Regulation No P.76/2015. This option aimed to 'update' the existing zones so that the management area at Gunung Kembar 
and Gunung Waihlup is changed to a utilization zone if all the prerequisites are met. The said regulation stipulates that the management zone in a national park can be evaluated periodically at most every ten years, according to the results of the area's potential inventory. This evaluation can be done in certain conditions, among others, changes in the region, natural disasters, wildfires, pests and diseases, evaluation of management zones or blocks of nature conservation areas and nature reserve areas may be conducted following the interests of management. The assessment results can be used as the basis for the proposal to change the management zone applicable to the national park if the criteria meet the requirements stipulated in the statutory provisions.

Referring to the provisions governing rezonings, in the context of GLNP, efforts can still be made to change or evaluate the management zones following management interests, which is the interest to utilize the geothermal potential. However, there is no guarantee that this option can be the solution for the geothermal exploitation in GLNP, considering that there is a possibility in which the Directorate General of Living Natural Resources and Their Ecosystem (Dirjen KSDAE) would decline such a proposal. Article 10 of the Director-General of Living Natural Resources and Ecosystem Regulation No P.14/KSDAE/SET/ KSA.0/9/2016 stipulates that the evaluation of core zones or protection blocks which has potential and specific conditions for exploitation such evaluation requires a proper study by the working teams and by involving experts. Thus, it can be inferred that changes to the core zone of GLNP are feasible by law.

The management zone's evaluation is to be carried out according to Director-General Regulation No P.14/KSDAE/SET/KSA.0/9/2016 on Technical Guidelines on the Evaluation of Management Zone or Management Block of Nature Conservation Area and Nature Reserve Area. The regulation was mandated by the provision of Ministerial Regulation No. P.76/2015.

The option to change the management zones is more feasible because the preliminary geothermal survey had been conducted, which can be used to propose such changes based on the inventory of the potential in the area (Ministerial Regulation No. P.76, 2015). Such efforts can also be supported by the government's urgency to achieve the target of the NRE mix, in which geothermal plays an important role. Furthermore, the effort to utilize the geothermal potential in GLNP by updating the existing management zones can ensure that the changes should still consider conservation efforts to maintain balance.

The government should take measures to balance out the development of clean energy sources and the protection of conservation areas by minimizing the environmental impacts of the exploitation activities. In taking this step, the government can consider E. Meijaard et al., 2019's recommendations in their work, "Rapid Environmental and Social Assessment of Geothermal Power Development in Conservation Forest Areas of Indonesia"(Meijaard et al., 2019, pp. 57-66). 


\section{B. Potential Impact of Geothermal Power Plant Exploitation in Gunung Leuser National Park on the Status of Tropical Rainforest Heritage of Sumatra as A World Heritage Site}

Based on the conclusions in the previous section, it is found that there are still opportunities to conduct geothermal power plant exploitation in GLNP, one of which is by proposing changes to the management zones. Nevertheless, another aspect that must be considered is that GLNP is part of TRHS with two other national parks (i.e., Kerinci Seblat National Park and Bukit Barisan Selatan National Park). The status was awarded in 2004 by UNESCO because TRHS is considered a natural heritage that has Outstanding Universal Value (hereinafter OUV) (WHCom, 2004).

The acknowledgment of the world heritage site is introduced by the Convention Concerning the Protection of the World Cultural and Natural Heritage 1972 (hereinafter World Heritage Convention), which focuses on protecting cultural and natural heritage. The Convention provides the opportunity for states to nominate cultural and/or natural wonders within their territory to be recognized and included in the World Heritage List (World Heritage Convention, 1972).

TRHS got recognition as a world natural heritage site because it met some of the criteria set by the World Heritage Committee (hereinafter WHCom) as having OUV. The evaluation from WHCom showed that TRHS fulfilled three criteria as stipulated in the Operational Guidelines for the Implementation of the World Heritage Convention (hereinafter Operational Guidelines WHC). TRHS fulfilled three criteria according to the WHCom Decision No. 28 COM 14B.5, namely: criterion (ii), (iii), and (iv). Referring to the provisions in paragraph 77 of Operational Guidelines WHC, those three criteria were defined as follow:

"criterion (ii): exhibit an important interchange of human values, over a span of time or within a cultural area of the world, on developments in architecture or technology, monumental arts, town-planning or landscape design; criterion (iii): bear a unique or at least exceptional testimony to a cultural tradition or to a civilization which is living or which has disappeared; criterion (iv): be an outstanding example of a type of building, architectural or technological ensemble or landscape that illustrates a significant stage in human history."

Among the benefits of such recognition is the financial assistance in the form of the World Heritage Fund to protect the site (World Heritage Convention, 1972, Chapter 4). According to the World Heritage Convention, another benefit that the states can expect is international assistance on staff training, provision of equipment, and loan. The recognition as a world heritage site is also believed to promote tourism due to the WHCom secretariat's publications (Frey \& Steiner, 2011, pp. 555-573; Operational Guidelines WHC, 2019, paras. 288-290). According to WHCom, TRHS has received assistance from the World Heritage Fund a total of US\$96.600 in 2005 and 2012. 
It is necessary to be noted that the status as a world heritage is not permanent. Instead, such status is evaluated annually by the WHCom through the state of conservation reports (Operational Guidelines WHC, 2019, para. 176). On the other hand, the member states must also provide reports related to the followup measures taken in accordance with the WHCom's recommendations. The site will be inscribed on the List of World Heritage in Danger category if it is considered to be in danger or at risk of danger.

Operational Guidelines WHC paragraph 180 stipulates that there are two types of threats that can result in a site's inscription on the List of World Heritage in Danger. The first type of threat is ascertained danger, which refers to a situation in which the property is dealing with "specific and proven imminent danger." The second type of threat is a potential danger, which refers to a situation in which the property is dealing with threats that "could have deleterious effects on its inherent characteristics." The conditions considered threatening the world heritage site are provided in Table 4 (Operational Guidelines WHC, 2019, para. 180).

Table 4. Criteria for the conditions considered threatening a world heritage site

(1) "A severe decline of the endangered species population or the
other species of OUV for which the property was established to
protect, either by natural or human-made factors."
(2) "Severe deterioration of the property's natural beauty or scientific
value caused by human settlement, construction of reservoirs
which flood important parts of the property, industrial and
agricultural development including the use of pesticides and
fertilizers, major public works, mining, pollution, logging,
firewood collection."
Dancertained
(3) "Human encroachment on boundaries or in upstream areas which
threaten the integrity of the property."
(1) "A modification of the legal protective status of the area."
(2) "Planned resettlement or development projects within the
property or so situated that the impacts threaten the property."
(3) "Outbreak or threat of armed conflict."
(4) "The management plan or management system is lacking or
inadequate or not fully implemented."
(5) "Threatening impacts of climatic, geological, or other
environmental factors."

Source: Compiled by the authors from the Operational Guidelines WHC 2019.

Should a property be listed on the List of World Heritage in Danger, WHCom will give the state recommendations to take necessary actions to overcome the threats. However, in the event where the property is deemed to be damaged or has lost its essence of OUV and the state failed to take timely remedial action, the WHCom may revoke the property's recognition as a world heritage site. (Operational Guidelines WHC, 2019, para. 192).

In 2011 and every year since, TRHS has been included in the list of World Heritage in Danger (WHCom, 2011). Based on the report WHCom No. WHC- 
11/35.COM/7B.Add, among the issues that became the basis to put TRHS in the list are as follows:

1) Road construction

The road constructions that have been carried out since the earthquakes in West Sumatra in 2009 were deemed the cause of the threat, particularly the construction of road infrastructures via Kerinci Seblat National park. Besides, there were also plans from the local government to conduct the construction of four new roads to support evacuation and economic development necessity. Such a project was deemed a threat by the International Union for Conservation of Nature (hereinafter IUCN) because it cuts through and potentially disrupts the native habitat of Sumatran tigers, which is considered the OUV of TRHS. Around the same time, the Ministry of Forestry also had given road construction permits to connect the roads from Sukabumi to Way Hayu. The route Way Heni-Sukaraja was deemed to disrupt the habitat of Sumatran rhino and the ecosystem's balance.

2) Agricultural expansion

Satellite observations revealed that the deforestation rate in TRHS was alarming, reaching 1200 hectares/year in Bukti Barisan Selatan, 2000 hectares/year in Kerinci Seblat, and 625 hectares/year in Gunung Leuser. Other reports also suggested there were forest clearing activities for palm oil, cocoa, and rubber plantation near the orangutan habitat.

3) Illegal mining

It was indicated that there were illegal mining activities in the area of Bukit Barisan Selatan. Some reports also indicated plans to develop mining activity in the area of GLNP by the local government.

4) Poaching

The Government of Indonesia did not report on poaching activities; nevertheless, the IUCN report found two elephants shot by poachers.

5) Expansion of city

The expansion of cities by the government overlaps with TRHS. There were 14 new districts established surrounding and overlaps with Kerinci Seblat National park, which was deemed to complicate the property management and increases development threats, including form road construction.

6) Monitoring System

Satellite surveillance indicated that invasive species had inflicted around 7000 hectares of forest areas in Bukit Barisan Selatan National Park. Indonesia was then asked to assess the factors that affect the property's OUV effectively.

7) Institutional coordination mechanism

Although the government has taken the initiative to improve property management cooperation and has made agreements with several 
stakeholders, the IUCN believed Indonesia should develop a clear mechanism

for institutional coordination to monitor the property's sustainability.

As of 2019, through Decision 43 COM 8C.2, the WHCom decided to keep TRHS in the List of World Heritage in Danger. The decision was based on the reasons that there were still threats to TRHS relating to deforestation and road construction (WHCom, 2019).

Considering the facts mentioned above, it becomes crucial for the government to project the impact that geothermal exploitation in GLNP will have on the TRHS status as a world heritage site, which, even at the moment, is already considered to be at risk of danger. The geothermal exploitation activities in GLNP would inevitably cause environmental impacts, i.e., forest clearing and/or road construction. We can immediately identify that there is an overlap of conflicting interests. On the one hand, the government has an interest in achieving the target of the NRE portion in the energy mix. While on the other hand, the government also has an interest in protecting the living natural resources within GLNP to overcome the existing threats. Those two sides of interests are mutually exclusive; therefore, the government needs to consider which interest will better suit the national needs.

Indonesia's intention to exploit the geothermal energy within the world heritage site had been discussed by the WHCom previously. In 2013, Indonesia submitted its interest in utilizing the geothermal energy found in TRHS as one of the national policies. Responding to the plan, WHCom and IUCN expressed their concern about such intention. They recommended conducting an Environmental Impact Assessment (hereinafter EIA) in advance to calculate the potential impacts on the environment.

Based on the fact above, it can be concluded that the WHCom does not necessarily prohibit geothermal power plant exploitation activities inside a world heritage site. Instead, it emphasizes the requirement to conduct EIA beforehand to consider the potential impacts on the environment. Several countries have successfully undertaken geothermal power plant exploitation in their national parks, including the Philippines, Kenya, and Costa Rica (Guido-Sequeira, 2010, p. 2). Several countries' practices show that the exploitation of geothermal energy and forest conservation may go hand in hand (Guido-Sequeira, 2010, pp. 4-5; Rybach, 2003, pp. 463-470). However, such practices do not, in any way, indicate that geothermal exploitation will not pose a threat to the environment at all. It boils down to whether the government's attempt to mitigate the impacts is comprehensive enough (Hannah, 1990, pp. 239-244).

Specifically, for the geothermal exploitation in TRHS, the potential environmental impacts may be categorized both as ascertained danger and potential danger. Geothermal power plants tend to require large areas of land and infrastructures such as roads, which would pose risks of environmental degradation (Arnórsson, 2004, pp. 297-336; Shortall et al., 2015, pp. 391-406). 
Such threats correspond with the provision relating to ascertained danger stipulated in the Operational Guidelines of WHC. Simultaneously, the efforts to revise the management zone in GLNP may be regarded as modifying the area's legal protective status, which corresponds with the provision relating to potential danger. However, several works suggest that almost all adverse impacts potentially posed by the geothermal power plant exploitation can be minimized and mitigated (Arnórsson, 2004, p. 329; Dolor, 2006, pp. 8-9).

One of the government's efforts to avoid such negative impacts is by proposing changes to the boundaries of TRHS. According to the provisions in the Operational Guidelines of WHC chapter III.I, it is stipulated that the state may make a boundary modification of the property listed as a world heritage site (Operational Guidelines WHC, 2019, paras. 163-165). Such modifications are divided into two types, namely: minor modification and significant modification. A modification to the property boundary is classified as a minor in case there is no significant impact on the site coverage or OUV. Therefore, the modification can be done according to the procedures set out in annex 11 of WHC Operational Guidelines. Meanwhile, if a state intends make a significant modification to the boundary, it must be treated as a new nomination. The WHCom shall evaluate the proposal by a member state to modify the boundaries and decide whether the modification is considered a minor modification or a significant modification.

Based on the findings thus far, the government has the option to propose a boundary modification of TRHS to exclude the areas of GLNP, or to be more exact, the areas around Gunung Kembar and Gunung Waihlup. If such a request is granted, the geothermal exploitation activities would no longer pose risks to TRHS's status and the recognition as a world heritage site. However, the exploitation must still calculate the possible environmental impacts to the ecosystem and must always be based on a comprehensive EIA to identify and mitigate the consequences. Extra measures may also be necessary to ensure that the impacts on the ecosystem are contained not to affect the remaining areas of the TRHS.

Suppose the request to modify the boundaries of TRHS is not granted, then in the worst-case scenario. In that case, TRHS may lose its recognition due to the geothermal power plant exploitation in GLNP. In such a context, the Indonesian government needs to consider and weigh which interests would provide more significant benefits for the national needs (Hermawan, S, 2021). The Oman government has also faced a similar situation, which eventually decided to sacrifice the recognition as a world heritage site of Arabian Oryx Sanctuary to benefit from oil mining (Qin et al., 2019). Although initially, the Oman government tried to request boundary modification to leave $10 \%$ of the original area, which the WHCom refused to approve (Meskell, 2014).

In the worst-case scenario, the government needs to assess how urgent is the geothermal exploitation in GLNP and whether there is alternative geothermal potential in other places that we can tap optimally to reach the NRE target in the 
energy mix. Suppose a comprehensive calculation shows that the geothermal exploitation in GLNP is vital and irreplaceable. In that case, the option to sacrifice the status of TRHS as a world heritage site must be considered thoroughly. However, it is essential to note that even if the government chooses such option, it does not mean that conservation efforts in GLNP will also cease. In this context, the difference is that the government would have more flexible discretion (i.e., not constrained to accommodate the WHCom's recommendations) to balance electricity generation and conservation interests.

The efforts to safeguard conservation should not be abandoned entirely in any scenario because the government is still bound by the mandate of the Biodiversity Conservation Act and other relevant laws. Therefore, sacrificing the world heritage site status does not mean that the government may stop conservation efforts in GLNP, Bukit Barisan Selatan National Park, and Kerinci Seblat National Park.

\section{Conclusion}

Act No. 21/2014 cannot be used as a justification for geothermal exploitation in Gunung Kembar and Gunung Waihlup areas, located within the core zone of GLNP. However, it is possible by law to propose changes to the existing management zones of GLNP so that the prospective exploitation sites fall within a utilization zone. Such finding indicates that the geothermal exploitation in Gunung Kembar and Gunung Waihlup within GLNP is still feasible by law. Even though the exploitation is still possible in the best-case scenario, the geothermal exploitation within the GLNP is expected to negatively impact the conservation efforts, which would put TRHS world heritage site status further at risk.

Based on the findings concluded above, there are several recommendations for the government of Indonesia to consider. First, considering the impacts of geothermal exploitation for power plants on the conservation efforts and consequently on the status of TRHS, the government must prepare a policy study relating to the prioritization of national needs. Specifically, between the need for international recognition with all the benefits that come with it and the need for a sustainable energy supply to achieve national energy security. It should be noted that either scenario should not be interpreted as a setback or progress on the conservation efforts, as it will depend on how the government acts upon that decision.

Second, the government must first conduct EIA before deciding whether to carry out geothermal exploitation within the area of GLNP as a part of TRHS to measure the possible impacts on the natural environment. Should the government decided to conduct geothermal exploitation in GLNP, the government must first propose changes to the existing management zones of GLNP according to the procedures and requirements stipulated in the relevant regulations. The government may also try to request boundaries modification of TRHS to the WHCom, to exclude the prospective exploitation sites in Gunung Kembar and Gunung Waihlup or the entirety of GLNP from TRHS. 


\section{BIBLIOGRAPHY:}

\section{Books:}

Meijaard, E., Dennis, R.A., Saputra, B.K., Draugelis, G.J., Qadir, M.C.A., Garnier, S. (2019). Rapid environmental and social assessment of geothermal power development in conservation forest areas of Indonesia. Washington DC: PROFOR, The World Bank.

Ministry of Energy and Mineral Resources. (2016). Statistik EBTKE. Jakarta: Directorate General of New and Renewable Energy and Energy Conservation.

Ministry of Energy and Mineral Resources. (2017). Buku Potensi Panas Bumi Indonesia Jilid I. Jakarta: Directorate General of New and Renewable Energy and Energy Conservation.

Ministry of Energy and Mineral Resources. (2019a). Handbook of Energy E Economic Statistic of Indonesia 2019. Jakarta.

Ministry of Energy and Mineral Resources. (2019b). Indonesia Energy Outlook 2019. Jakarta: National Energy Council.

\section{Journal Articles:}

Arnórsson, S. (2004). Environmental Impact of Geothermal Energy Utilization, Geological Society London Special Publications, 236 (1), 297-336.

Frey, B.S., \& L. Steiner. (2011). World Heritage List: does it make sense?, International Journal of Cultural Policy, 17 (5), 555-573.

Hannah, L. (1990). Rainforests and Geothermal Energy in Hawaii: Environmental Concerns Expose Flawed State Planning Process, Journal of Environmental Conservation, 17 (3), 239-244.

Hermawan, S. (2021). Analysing several ASEAN countries' policy for combating marine plastic litter, Environmental Law Review Vol. 23, Issue 1, 9-22, https:// doi. org/10.1177/1461452921991731

Mary, R. T., Armawi, A., Hadna, A., \& Pitoyo, A. (2017). Panas bumi Sebagai Harta Karun untuk Menuju Ketahanan Energi, Jurnal Ketahanan Nasional, 23 (2), 93-113.

Meskell, L. (2014). States of Conservation: Protection, Politics, and Pacting Within UNESCO's World Heritage Committee, Anthropological Quarterly, 87 (1), 217-244.

Qin, S., Kroner, R. E. G., Cook, C., Tesfaw, A. T., Braybrook, R., Rodriguez, C. M., Poelking, C., \& Mascia, M. B. (2019). Protected Area Downgrading, Downsizing, and Degazettement as A Threat to Iconic Protected Areas, Conservation Biology, 33 (6), 1275-1285.

Rybach, L. (2003). Geothermal Energy: Sustainability and The Environment, Geothermics, $32,463-470$.

108 Yustisia Volume 10 Number 1 (Jan-Apr 2021) Geothermal Exploitation in a World Heritage Site... 
Sahide, MAK., Fisher, M., Maryudi, A., Dhiaulhaq, A., Wulandari, C., Kim, Y.-S., \& Giessen, L. (2018). Deadlock Opportunism in Contesting Conservation Areas in Indonesia, Land Use Policy, 77, 412-424.

Shortall, R., Davidsdottir, B., \& Axelsson, G. (2015). Geothermal Energy For Sustainable Development: A Review of Sustainability Impacts and Assessment Frameworks, Renewable and Sustainable Energy Reviews, 44, 391-406.

\section{Indonesian Law:}

Act No. 5 of 1990 on Conservation of Living Natural Resources and Ecosystem (Gazette of 1990, No. 49).

Act No. 41 of 1999 on Forestry (Gazette of 1999, No. 167).

Act No. 21 of 2014 on Geothermal (Gazette of 2014, No. 217).

Government Regulation No. 79 of 2014 on National Energy Policy (Gazette of 2014, No. $300)$.

President Regulation No. 22 of 2017 on General Plan of National Energy (Gazette of 2017, No. 43).

Ministerial Regulation No. P.76/ Menlhk-Setjen/2015 (Gazette of 2015, No. 164).

Director-General of Conservation of Living Natural Resources and Ecosystem Regulation No. P.14/KSDAE/SET/KSA.0/9/2016 on Technical Guidelines for the Evaluation of Management Zone and Management Block of Nature Conservation Area and Nature Reserve Area.

DPR Decision No. 4/DPR RI/III/2015-2016 on National Legislation Program 2015 2019.

DRP Decision No. 46/DPR RI/I/2019-2020 on National Legislation Program 2020 - 2024.

\section{Treaties and International Organization Decisions:}

United Nations Educational, Scientific, and Cultural Organization. Convention Concerning the Protection of the World Cultural and Natural Heritage. Adopted by the General Conference at its seventeenth session Paris. (16 November 1972).

World Heritage Committee. 2004. Decision 28 COM 14B.5 Nominations of Natural Properties to the World Heritage List (Tropical Rainforest Heritage of Sumatra).

World Heritage Committee. 2011. Decision 35 COM 8C.1 Establishment of the World Heritage List in Danger (Inscribed Properties).

World Heritage Committee. 2013. Conservation Issues in TRHS Based on Convention Concerning the Protection of The World Cultural and Natural Heritage 37th Session Phnom Penh, Cambodia.

World Heritage Committee. 2019. Decision 43 COM 11A Operational Guidelines for the Implementation of the World Heritage Convention. 


\section{Paper or Speech Presented in A Scientific Forum:}

F.M. Dolor. (2006). Geothermal Project in National Parks in the Philippines: The Case of The Mt. Apo Geothermal Project. Workshop for Decision Makers on Geothermal Projects in Central America, San Salvador, El Salvador, 26 November - 2 December 2006.

H. Guido-Sequeira. (2010). Geothermal energy exploration in Environmental Protected Areas in Costa Rica. Proceedings World Geothermal Congress 2010, Bali, Indonesia, 25-29 April 2010.

\section{Internet:}

Arief. (2020). Kerja Berat Pemenuhan Energi Aceh. Pikiran Merdeka. https://wwww. pikiranmerdeka.co/news/kerja-berat-pemenuhan-energi-aceh/. (Accessed 11 September 2020)

Gres News. (2020). Proyek Panas Bumi Turki Ancam Taman Nasional Leuser. http:// www.gresnews.com/berita/sosial/112469--proyek-panas-bumi-turki-ancam-tamannasional-leuser/. (Accessed 11 September 2020)

110 Yustisia Volume 10 Number 1 (Jan-Apr 2021) Geothermal Exploitation in a World Heritage Site... 